\title{
Human T cell lymphotropic virus type 1 (HTLV-1) infection increases the CD4 count in human immunodeficiency virus type 1 (HIV-1) infected patients submitted to antiretroviral therapy (ARV)
}

\author{
Filipe FA Rego ${ }^{1,2}$, Luiz CJ Alcantara ${ }^{1 *}$, Tulio de Oliveira ${ }^{2}$ \\ From 16th International Conference on Human Retroviruses: HTLV and Related Viruses \\ Montreal, Canada. 26-30 June 2013
}

To understand the impact of HTLV-1 in the CD4 counts in HIV coinfected patients from KwaZulu-Natal, 382 HIV-1 plasma samples with ARV failure were screened for HTLV-1. Out of 382 samples, eight were reactive in the EIA and seven were confirmed as HTLV-1 positive by PCR. The data from those patients was obtained in the RegaDB and was analyzed regarding the CD4 count using the STATA software. The prevalence of coinfection was $1.8 \%$ (7/382). The baseline CD4 count did not show statistical difference between groups before treatment. The overall CD4 count median during the ARV in coinfected patients (301cells/uL) was higher than in HIV-1 infected patients (232cells/uL $p=0.0002$ ). The CD4 count did not behave different between the groups along the time. This observation might be due to the higher treatment time in coinfected patients (median 1764days vs. 1459days, $\mathrm{p}<0.0001$ ), provided that in the end of therapy they were failing on the ARV but the paired analyze with viral load must be done whereas there is an inverse correlation between $\mathrm{CD} 4$ count and viral load. There was no difference regarding the age and gender between the groups. HIV-1/HTLV-1 co-infection seems to change the $\mathrm{CD} 4$ count ratio between positive and negative individuals on ARV.

\section{Authors' details}

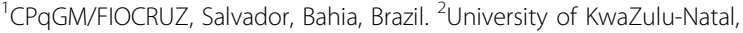

Durban, KwaZulu-Natal, South Africa.

Published: 7 January 2014

\footnotetext{
* Correspondence: lalcan@bahia.fiocruz.br

${ }^{1} \mathrm{CPqGM} /$ FIOCRUZ, Salvador, Bahia, Brazil

Full list of author information is available at the end of the article
}

doi:10.1186/1742-4690-11-S1-P62

Cite this article as: Rego et al:: Human T cell lymphotropic virus type 1 (HTLV-1) infection increases the CD4 count in human

immunodeficiency virus type 1 (HIV-1) infected patients submitted to antiretroviral therapy (ARV). Retrovirology 2014 11(Suppl 1):P62.
Submit your next manuscript to BioMed Central and take full advantage of:

- Convenient online submission

- Thorough peer review

- No space constraints or color figure charges

- Immediate publication on acceptance

- Inclusion in PubMed, CAS, Scopus and Google Scholar

- Research which is freely available for redistribution

Submit your manuscript at www.biomedcentral.com/submit
() Biomed Central 